killed some weeks after, showed no further lesion. sections of the nodules in the organs of the original guineapigs the typical tuberculons characteristics (giant cells and epithelioid cells) failed. The lesions were therefore probably occasioned, not by Koch's bacillns tuberculosis, but by an organism identical or similar to that described by Rabinowitsch and detailed above.

In Liverpool early in 1899 the experiments were continued with 13 samples collected from various shops in the city. Subcutaneous inoculation was practised, two guineapigs for each sample. In this case only two guinea-pigs died within 10 days-so that two samples had only one animal eacb. Out of these 13 samples only one proved to be tuberculous, the guinea-pig exhibiting post mortem the typical characteristics, both macro- and micro-scopically, of real tuberculosis. Inoculations from the lesions subcutaneously were followed by typical tuberculosis in guinea-pigs. Thus out of a total of 28 samples, 15 of Berlin and 13 of Liverpool margarine, only one proved to contain virulent bacillus tuberculosis of Koch, and that in a sample from the latter city.

I wish to take this opportunity of thanking my late colleagues at Professor Koch's Institute for their great courtesy and kindness towards me during the 18 months when I worked among them, and particularly Professor Koch, Professor Pfeiffer, Professor Brieger, and Professor Frosch for their help and advice during my researches.

Liverpool.

\section{THE FEASIBILI'TY OF CARRYING OUT THE OPEN-AIR TREATMENT OF CONSUMPTION AT THE PATIENT'S HOME;}

WITH AN ACCOUNT OF A SUCCESSFUL CASE.

By 'T. A. SOMERVILLE, M.R.C.S. ENG., M.O.H., AND

EUGENE S. YONGE, M.D. EDIN.,

HONORARY ASSISTANT PHYSICIAN TO THE MANCHESTER HOSPITAL FOR CONSUMPTION AND DISEASES OF THE THROAT.

THE statement recently made by a distinguished physician ${ }^{1}$ that in 95 per cent. of the cases of phthisis seen by the medical practitioner the patients are unable to afford treatment away from their homes, does not appear to us to be very wide of the mark. And in addition to the item of expenditure there are, amongst other disabilities which bar the way to effective treatment, those salient ones of severance from home; the cessation, in the case of the bread-winner, of the family income; and the depressing influence, to some temperaments, of an environment of sick people; all of which render it advisable to possess a substitute for the treatment by sanatorium or sea-royage when such methods are impracticable.

The following case was an example of acute pulmonary consumption in which the patient adopted, and was apparently cured by the open-air treatment carried out at his own residence. He kept in touch, at the same time, with a large city business which, for certain specific reasons, he was unable to leave in other hands-a procedure which would have been inevitable had treatment away from home been agreed to. The patient, a merchant, aged 30 years, consulted one of us in the latter part of May, 1899, complaining of congh, especially in the morning, scanty mucopurulent expectoration, and hoarseness. He also suffered from foss of appetite, nausea after food, and considerable loss of weight-seven or eight pounds since the beginning of May. The patient stated that he lacked all energy, was unrefreshed by sleep, feverish, and troubled with night-sweats. He had had, according to his own account, an attack of influenza early in May, about which time the symptoms enumerated began. The supposed attack of influenza was marked by repeated chills, indefinite pains, and fever. Up to that date he had been in fairly good health, although the exigencies of his business had caused

1 Osler: The Home Treatment of Consumption, Brit. Med. Jour. Epit., Dec. 16th, 1899. him a great deal of work and worry, and he had been, in consequence, rather "burning the candle at both ends." On examination there was some loss of resonance and of expansion at both apices, with increased vocal fremitus, bronchophony, harsh breathing, and prolonged expiration at the left apex. There was a faint systolic mitral murmur and accentuation of the pulmonary second sound. The temperature averaged $102^{\circ} \mathrm{F}$. in the morning and $103^{\circ}$ in the evening. The larynx was in a condition of catarrhal inflammation, and microscopic examination of the sputum revealed large numbers of tubercle bacilli. The congh, pyrexia, and other symptoms continued without much change for about three weeks. On June 29th the patient was seen by us in consultation and we considered the case to be one of early acute pulmonary phthisis with a catarrhal laryngitis, possibly pretuberculous. The condition of matters was explained to the patient and the various methods of carrying out the open-air treatment were discussed. He was extremely unwilling to take a voyage or to leave his home for any length of time, as he felt that the neglect of his business, which was a personal one, would result in serious trouble, and both he and his friends were so much opposed to the usual sanatorium treatment that the idea was relinquished.

Creasote, maltine, and an inhalant were prescribed; a liberal diet was enjoined and the patient was advised to spend as much time as possible in the open air. His house was, fortunately, situated in the country, at a village about 12 miles from the city where he carried on his business. Although in no sense a health resort, the elimatic and sanitary conditions of the village are good. The death-rate is 14 per 1000 and there are few indigenous cases of phthisis. The rainfall for 1899 was 2625 inches and there is seldom any fog. The patient's residence, which is built on sandy soil, faces south-east. $O n$ Angust 9th, after adopting the modified treatment indicated above for about six weeks, the patient was again seen in consultation; and the condition then reported was that the cough, night-sweats, and anorexia had all considerably lessened; the nocturnal temperature had fallen to $99^{\circ}$ and a gain in weight of 16 pounds had accrued. An examination of the lungs, however, showed that the tuberculous process was still active. There were signs of softening at the right apex and at the right base there was a small patch of pleurisy. The left apex and the larynx were practically in statu quo. It was therefore suggested that he should carry out the open-air treatment quite systematically and that it should be supplemented by moderate over-feeding and graduated exercise under our supervision. The method then adopted was to spend at least six or seven hours daily in the open air, either walking about slowly or driving, or sitting in the garden. The "lung gymnastics" recommended by Dettweiler were frequently practised. ${ }^{2}$ If the weather were wet the patient sat in a shelter (summer-house) facing the south; or if not very rainy he took short walks clothed in suitable garments - which he exchanged for dry ones as soon as he came indoors-and thick waterproof boots. The windows in his bedroom and in the sitting-room which be occupied always remained widely open. His friends at first objected to this excessive ventilation but soon got accurtomed to it. As the weather grew colder it was found advisable for the convenience of visitors to the house that one receiving-room should be set apart for the patient, and another, more in consonance with modern ideas of ease, for those who objected to such "cold comfort" as the invalid could dispense. On one day in each week the patient spent a few hours at his office, returning to the country as soon as possible. The diet was not rigidly prescribed, but the principles of moderate over-feeding were explained and the patient was advised to eat a little more than he felt inclined to. Roughly speaking, the daily menu was as follows : At 4 A.M., half a pint of milk (with half a wineglassful of whisky). $8.30 \mathrm{~A} . \mathrm{M}$. breakfast: tull meal of fish or eggs with, perhaps, a small quantity of stewed fruit. At 10 A M , balf a pint of milk containing a raw egg. At 1.30 P.M. dinner, consisting of three courses, the food being as varied as possible each day. Cheese was always taken. At 4 P.M., afternoon tea. At 6.30 P.M., half a pint of milk containing a raw egg. At 9 P.M., a large plateful of porridge with milk ad lib. The results of this diet were that in the first week the invalid gained two and a half pounds. In the

2 During steady walking five or six deep breaths are taken through the nose $\epsilon$ very 100 or 150 paces; or when lying in the open air, 10 or 12 detp breaths every tive or 10 minutes. 
second week the digestive organs rebelled somewhat. The patient suffered from gastric catarrh and lost one pound and he also felt generally less well. During the third week the gastric symptoms disappeared and two pounds in weight were superadded. After that time he gained, on an average, one pound per week up to Oct. 13th (about three and a half months from commencing treatment), when he found that he had gained an aggregate of 28 pounds, or an average on the whole time of about two pounds per week. His present weight (Jan. 1st, 1900), seven months after commencing treatment, is $10 \mathrm{st} .11 \mathrm{lb}$, an increase of $2 \frac{1}{2} \mathrm{st}$. in that time.

The total effect of the combined fresh air, the feeding, and the exercise was that, in addition to the gain of weight, the cough and expectoration rapidly and entirely disappeared, the night-sweats vanished, he had no return of the dyspepsia, the temperature kept within normal limits, the larynx returned to its normal condition, and the patient, on Oct. 13th (about two months after commencing the open-air treatment systematically), appeared both subjectively and ojjectively to be perfectly well. The condition of the lungs at this date was, no abnormal dulness at either apex, expan. sion good, breath sounds vesicular, and expiration not prolonged. The moist râkles had quite vanished. Re-examinations of the sputum have failed to give any evidence of tubercle bacilli. The patient informs us that he spent one of the six months during which he was under treatment at Rbyl in North Wales. He wrote to us last at the end of December, 1899, and reported himself as being perfectly well.

The case described above appears to have been an acute tuberculous broncho-pneumonia, an instance of one of the commoner forms in which phthisis florida, or what is popularly known as "galloping consumption," is met with. 'The loss of flesh and strength in such patients is very striking, and frequently out of proportion to the physical signs. The temperature is high, the pulse is rapid, and the respirations are increased. There may be repeated chills, as in the instance of our patient; and we suspect that the symptoms noted early in May were attributable to the tubercle bacillus rather than to the organism of influenza. Three points greatly in favour of the method adopted were the incipiency of the disease, the power which the patient enjoyed of securing abundant good food and favourable surroundings in the country, and the intense interest which both he himself and his friends took in the treatment. Perhaps the most serious indictment which has been brought against the home treatment of early phthisis is the absence of that discipline which prevails in sanatoria, and without which it would sometimes be impossible to enforce what may appear to the lay mind as annecessarily drastic measures. The only remedy for this appears to be the substitution, in a measure, of the authority of the practitioner in attendance for that which would appertain to the director of a sanatorium, were the patient in such an institution, and the early settlement of the rival claims, on the one hand, of the patient's friends and, on the other hand, of the medical man, to conduct the treatment of the case. If the practitioner feels unequal to the task of breaking through the phalanx of lay jonorance and prejudice with which he may be confronted, it appears to us far better to advise that the patient be sent to a sanatorium.

It is possible for any phthisical patient living in the country and possessing a garden in which a small shelter can be erected to carry out the treatment; but he should be under the strict supervision of his medical man who takes the thermometer as his principal guide to the amount of exercise, \&c., which the patient is to practise. Daily supervision of this kind was carried out in the case quoted above. The shelter, facing the south, should contain a couch or chair and be provided with moveable curtains or shutters to keep out the cold winds and driving rain. The open-air treatment nught not to be intermittent, but carried on throughout the 24 hours, the windows being widely opened when the patient cannot be out of doors.

But although the home treatment of consumption will in all probability yield the best results where the pinch of poverty is not felt, it does not follow that the poor are altogether debarred from its advantages. Osler, ${ }^{3}$ in a recent paper, has adrocated its employment for the benefit of this slass of patient. And whilst he admits that the quality of fresh air in large cities may not be very good, he remarks that it is the best that a large proportion of our patients

3 Loc. cit. have to breathe, and it is considerably superior to the atmosphere of the ill-ventilated, over-heated rooms in which the majority of them live. Even for those of the poorer classes who apply at a hospital for consumption when the disease is in its curable stage, there are many weary days of "waiting for beds" when effectual treatment is practically in abeyance, when valuable time is being lost, and the patient is slipping towards the boundary which delimits the possibility of cure. For such as these Osler gives the following directions :Take the almanack and count off the hours of sunshine. In the winter cut off two hours in the morning and one hour in the evening, and for the rest of the day the patient must be out of doors. If there is no possible arrangement for life out of doors the patient must be put in a room with a southern exposure and the bed moved in the sunshine, with the windows wide open. If there is a balcony or verandah with a good outlook towards the south it should be arranged for the patient; if not, a shelter could be put up in the yard at a very moderate cost. On a well-padded lounge, covered with a couple of thicknesses of blankets, the patient sits or reclines all day. Only on blusterous, stormy, or very rainy days is the patient to remain in the house. No degree of cold is a contra-indication.

We have drawn attention to the case reported above with a view of stimulating the home treatment of consumption in those instances where treatment at a sanatorium-which is preferable if possible-is found to be, for some reason, impracticable; and also with the idea of counteracting the feeling which some of the profession entertain towards the sanatorium treatment, that in the management and cure of early phthisis the axiom aut sanatorium aut ninil practically sums up the whole position.

\section{de attirtor}

\section{HOSPITAL PRACTICE,}

\section{BRITISH AND FOREIGN.}

Nulla autem est alia pro certo noscendi via, nisi quamplurimas et morborum et dissectionum historias, tum aliorum tum proprias collectas habere, et inter se comparare.-MorgagNI De Sed. et Caus. Morb., lib. iv. Proœmium.

\section{GUY'S HOSPITAL.}

A CASE OF SEVERE INTRA-UTERINE H EMORRHAGE FROM CYSTIC MOLAR PREGNANCY.

\section{(Under the care of Mr. J. H TABgETT.)}

A woman, aged 28 years, was admitted into Guy's Hospital on Sept. 29th, 1898, for swelling of the abdomen and vaginal hæmorrbage. She had had four full-term and normal parturitions and no miscarriages. Her last confinement was on July 15th, 1897, and she nursed the child for about a year. Menstruation returned during the latter part of her lactation and her last menstrual period began on July 1st, 1898. On August 15th she had a sudden hæmorrhage from the vagina and began to be sick, but she bad no idea that she was pregnant. The bleeding occurred whilst the patient was at supper and was accompanied with sharp pain in the right iliac region and groin. It recurred at intervals during the night and the next day she was better, but on the third day the hæmorrhage became continuous and the vomiting was frequent. There was no abdominal enlargement at this time, but from the onset of the bleeding until the date of admission the abdomen had steadily increased in size. Micturition was frequent and the bowels were much confined.

When admitted to the hospital more than six weeks after the onset of the bæmorrhage the patient was decidedly blanched and much wasted. The temperature ranged between $99^{\circ}$ and $100.5^{\circ} \mathrm{F}$. The breasts were very small and lax; they contained no secretion and showed no recent pigmentation. The abdomen was occupied by a large central s welling of the size of a seven months' gestation. It was pyriform in shape, rising out of the pelvis to the level of the ninth costal cartilages, and had a uniform outline. The tumour had an elastic feel and gave a most distinct thrill $f$ in all directions, but it hardened on palpation like the 